\title{
Interaction of organic acids and pH on multi-heavy metal extraction from alkaline and acid mine soils
}

\author{
Y. Z. Ding $\cdot$ Z. G. Song $\cdot$ R. W. Feng $\cdot$ \\ J. K. Guo
}

Received: 26 October 2011/Revised: 5 June 2012/ Accepted: 23 August 2012/Published online: 11 December 2013

(C) Islamic Azad University (IAU) 2013

\begin{abstract}
Vegetation at mining sites can produce increased heavy metal leaching by the organic acids and protons originating from root secretion and litter degradation. Batch experiments were conducted to investigate the effects of organic acids and $\mathrm{pH}$ on the extraction of $\mathrm{Pb}, \mathrm{Cd}, \mathrm{Zn}$ and $\mathrm{Cu}$ from an alkaline mine soil (sampled from a mining site of Chenzhou City, Hunan Province) and an acid mine soil (sampled from a mining site of Daxin county, Guangxi Province). The results showed that in the presence of organic acids (acetic, oxalic, malic, fumaric, tartaric and citric acids) at $\mathrm{pH} 7$, the extraction of $\mathrm{Pb}, \mathrm{Cd}, \mathrm{Zn}$ and $\mathrm{Cu}$ from the acid mine soil was much higher than that from the alkaline mine soil, in which only citric acid with higher concentration was capable of extracting some heavy metals. Citric acid had the strongest ability in extracting heavy metals, followed by oxalic acid. Heavy metal extraction dramatically decreased with increasing $\mathrm{pH}$. Moreover, at low $\mathrm{pH}$, oxalic acid promoted the risk of $\mathrm{Cu}$ leaching; at high $\mathrm{pH}$, the leaching of $\mathrm{Pb}, \mathrm{Zn}, \mathrm{Cd}$ and $\mathrm{Cu}$ was enhanced by both oxalic and citric acids. This indicated that those plants, which can produce substantial citric acid or oxalic acid by root secretion and litter degradation, should not be selected for the revegetation of mining sites.
\end{abstract}

Y. Z. Ding $(\bowtie) \cdot$ Z. G. Song · R. W. Feng · J. K. Guo

Agro-Environmental Protection Institute, Ministry

of Agriculture, No. 31, Fukang Road, Nankai District,

Tianjin 300191, People's Republic of China

e-mail: yzhding@hotmail.com

Y. Z. Ding · Z. G. Song · R. W. Feng · J. K. Guo Key Laboratory of Production Environment and Agro-product Safety, Ministry of Agriculture, Tianjin 300191,

People's Republic of China

Y. Z. Ding · Z. G. Song · R. W. Feng · J. K. Guo

Tianjin Key Laboratory of Agro-environment and Food Safety,

Tianjin 300191, People's Republic of China
Keywords Chelating · Contamination - Leaching · Mining $\cdot$ Trace metals $\cdot$ Revegetation

\section{Introduction}

The exploitation of mineral resources provides us with strategic resources, but also causes environmental pollution and ecological damage. In China, the total destroyed and occupied land due to mining has reached 7.43 million $\mathrm{hm}^{2}$ and is estimated to increase annually by $40,000 \mathrm{hm}^{2}$ (Qiu et al. 2009). Multi-metal pollution in the soils within the vicinity of mines has become one of the most serious environmental issues (Conesa and Schulin 2010). These heavy metals may be released via the erosion of wind and water and can ultimately enter the food chain (Navarro et al. 2008). Today, great efforts are being made to remediate polluted mining sites, in which revegetation or phytostabilization is considered to be an efficient way to achieve long-term reclamation (Arienzo et al. 2004; Mendez and Maier 2008a, b). However, disadvantageous consequences after revegetation cover may arise due to organic acids excreted by the roots and/or decomposed by the litters of inhabiting plants. It was evidenced that organic acids could enhance the desorption of heavy metals from soils, resulting in more heavy metals leaching into the water body (Zhu et al. 1999). Lu et al. (2007) showed that exchangeable $\mathrm{Cd}$ was positively related to total organic acids in rhizosphere soils. Burckhard et al. (1995) found that organic acids, especially citric acid, promoted the leaching of $\mathrm{Zn}$ in mine tailings.

Low molecular weight organic acids, mainly originating from the decomposition of soil organic matter, plant root exudates and microbial metabolites (Jones 1998; Strobel 2001), play important roles in controlling the solubility of 
heavy metals and their subsequent uptake by plants due to the chelation or complexation between organic acids and heavy metals (Krishnamurti et al. 1997; Han et al. 2006). Naidu and Harter (1998) reported that organic ligands increased the extractability of $\mathrm{Cd}$ from soils. It was found that citric acid could significantly reduce $\mathrm{Cd}$ adsorption on soils due to the formation of soluble $\mathrm{Cd}$-organic complexes (Zhou et al. 2003). Schwab et al. (2008) found that citric acid greatly enhanced the movement of $\mathrm{Zn}$ and $\mathrm{Cd}$ in soils, but had little influence on $\mathrm{Pb}$ movement. And some researchers also found that citrate had the most efficiency in releasing $\mathrm{Cd}, \mathrm{Pb}$ and $\mathrm{Zn}$ than other organic acids (Wuana et al. 2010; Vesely et al. 2011). Low concentration of tartrate and citrate inhibited the desorption of $\mathrm{Cd}$ and $\mathrm{Cu}$, but high concentration of tartrate and citrate promoted the desorption (Gao et al. 2003). Citric acid, malic acid and acetic acid more effectively desorbed $\mathrm{Cu}, \mathrm{Cd}$ and $\mathrm{Pb}$ from soils than inorganic salts such as $\mathrm{CaCl}_{2}$ and $\mathrm{NaNO}_{3}$ (Qin et al. 2004). Increasing citric, oxalic or malic acid concentrations resulted in increases in $\mathrm{Cd}$ adsorption on acidic paddy and red soils at low $\mathrm{pH}$, but citric acid dramatically increased Cd solubility at high $\mathrm{pH}$ (Ding et al. 2008). These results suggested that organic acids might stimulate either the solubility or the immobility of heavy metals in soils, depending upon the type and concentration of organic ligands, the type of metals, the soil properties and other environmental factors (Collins et al. 2003; Ding et al. 2008).

In order to choose suitable plant species for revegetation of mining sites, people must investigate the leaching risks of heavy metals affected by organic acids and protons from root exudates and litter degradation. Stresses to plants resulting from nutrient deficiency and heavy metal toxicities in mine soils often induce increased root exudates that are rich in organic ligands (Ryan et al. 2001). It is still unclear whether organic acids are exuded by roots as free acids or alkali metal salts (Jones 1998). In any case, the acidity of rhizosphere soil is usually different from that of bulk soil, and many plants can contribute to soil acidification (Zhu et al. 1999). Although the effect of organic acids on the solubility of heavy metals has been researched widely, people are still unclear about the interaction among organic acids, $\mathrm{pH}$ and heavy metals in mine soils. Better understanding the interactions will help to construct more environmentally friendly vegetative covers in mining sites and decrease the leaching of heavy metals into the ambient surroundings.

In order to clarify the interaction of organic acids and $\mathrm{pH}$ on the leaching of multi-heavy metals from mine soils, two typical mine soils (an alkaline soil and an acid soil) in South China were selected, and the effects of organic acids on the extractability of $\mathrm{Pb}, \mathrm{Cd}, \mathrm{Zn}$ and $\mathrm{Cu}$ were investigated under different concentrations and different acidity. The study was carried out in Agro-Environmental Protection Institute, Ministry of Agriculture, Tianjin, in AugustSeptember, 2010.

\section{Materials and methods}

\section{Soil sampling}

An alkaline mine soil (Chenzhou soil) and an acid mine soil (Daxin soil) were sampled from mining sites of Chenzhou City $\left(112^{\circ} 13^{\prime}-112^{\circ} 55^{\prime} \mathrm{E}, \quad 25^{\circ} 27^{\prime}-26^{\circ} 13^{\prime} \mathrm{N}\right)$, Hunan Province, and Daxin county $\left(106^{\circ} 39^{\prime}-107^{\circ} 29^{\prime} \mathrm{E}\right.$, $22^{\circ} 29^{\prime}-23^{\circ} 05^{\prime} \mathrm{N}$ ), Guangxi Province, respectively. Both soil samples were collected from the surface layer $(0-20 \mathrm{~cm})$ and were air-dried, ground to pass through a 60-mesh sieve $(0.25 \mathrm{~mm})$, and stored for analysis.

Soil pH was measured in distilled water at a soil-tosolution ratio of 1:2.5 (w:v). The content of soil organic matter (SOM) was determined by the method of Nelson and Sommers (1996). Cation exchange capacity (CEC)

Table 1 Properties of the mine soils studied

\begin{tabular}{lrr}
\hline Item & Chenzhou soil & Daxin soil \\
\hline $\mathrm{pH}\left(\mathrm{H}_{2} \mathrm{O}\right)$ & $7.93 \pm 0.01^{\mathrm{a}}$ & $6.28 \pm 0.02$ \\
$\mathrm{CEC}\left(\mathrm{cmol} \mathrm{kg}^{-1}\right)$ & $43.2 \pm 0.28$ & $11.2 \pm 0.07$ \\
Organic matter $\left(\mathrm{g} \mathrm{kg}^{-1}\right)$ & $3.89 \pm 0.53$ & $25.58 \pm 1.61$ \\
$\mathrm{~Pb}\left(\mathrm{mg} \mathrm{kg}^{-1}\right)$ & $7,200 \pm 14.6(350)^{\mathrm{b}}$ & $829.5 \pm 3.73(250)$ \\
$\mathrm{Zn}\left(\mathrm{mg} \mathrm{kg}^{-1}\right)$ & $2,471 \pm 12.7(300)$ & $4,130 \pm 14.5(200)$ \\
$\mathrm{Cu}\left(\mathrm{mg} \mathrm{kg}^{-1}\right)$ & $2,020 \pm 13.5(100)$ & $29.2 \pm 0.11(50)$ \\
$\mathrm{Cd}\left(\mathrm{mg} \mathrm{kg}^{-1}\right)$ & $77.4 \pm 0.91(1.0)$ & $45.87 \pm 0.49(0.3)$ \\
\hline
\end{tabular}

${ }^{\mathrm{a}}$ Mean $\pm \mathrm{SD}(n=3)$

b Values in brackets are the National Soil Environmental Quality Standard of China 
was determined by the method of Bao (Bao 2000). Total concentrations of $\mathrm{Pb}, \mathrm{Cd}, \mathrm{Zn}$ and $\mathrm{Cu}$ in the soils were determined by $\mathrm{HF}-\mathrm{HClO}_{4}$ digestion (Tessier et al. 1979) and ICP-OES analysis (Optima 2000 DV, PerkinElmer, America). Accuracy was evaluated by the use of a certified reference material (Institute of Geophysical and Geochemical Exploration, NO. GBW07430). Multi-element standards, which were used as the certified reference material, were purchased from Sigma-Aldrich Co. LLC. All other reagents were analytical-reagent grade and were obtained from Sinopharm Chemical Reagent Beijing Co., Ltd. The physicochemical properties of both mine soils are listed in Table 1 . Both mine soils were heavily polluted with $\mathrm{Pb}, \mathrm{Cd}, \mathrm{Zn}$ or $\mathrm{Cu}$ compared with the individual National Soil Environmental Quality Standard of China (GB 15618-1995). Although the $\mathrm{Cu}$ concentration in the Daxin soil was not high, the data are still shown in this study for comparison with that of the Chenzhou soil.

Organic acids tested

Acetic acid, oxalic acid, malic acid, fumaric acid, tartaric acid and citric acid were selected to extract heavy metals $(\mathrm{Pb}, \mathrm{Cd}, \mathrm{Zn}$ and $\mathrm{Cu})$. These organic acids are commonly present in soils, and the tested concentrations ranging from 0 to $10.0 \mathrm{mmol} \mathrm{\textrm {L } ^ { - 1 }}$ are reasonable for soils, especially in the rhizosphere soils (Krishnamurti et al. 1997; Jones 1998). The organic acids were purchased from SigmaAldrich Co. LLC.
Extractability of $\mathrm{Pb}, \mathrm{Cd}, \mathrm{Zn}$ and $\mathrm{Cu}$ in mine soils by different organic acids with initial $\mathrm{pH} 7$

Organic acid solutions were prepared, with the concentration of $0,0.2,0.5,1.0,2.0,5.0$ and $10.0 \mathrm{mmol} \mathrm{L}^{-1}$, respectively. All solutions contained a background electrolyte of $0.01 \mathrm{~mol} \mathrm{~L}^{-1} \mathrm{NaNO}_{3}$, and solution $\mathrm{pH}$ was adjusted to $\mathrm{pH} 7$ using diluted $\mathrm{NaOH} / \mathrm{HNO}_{3}$. A total of $1.5 \mathrm{~g}$ soil was placed in a $50-\mathrm{mL}$ polypropylene centrifuge tube, $30 \mathrm{~mL}$ organic acid solution was added, and then 2 drops of toluene was added to inhibit microbial activity (Naidu and Harter 1998). The suspension was shaken endover-end for $5 \mathrm{~h}$ at $25^{\circ} \mathrm{C}$, centrifuged at $3,000 \mathrm{~g}$ for $15 \mathrm{~min}$, and then filtered using $0.45-\mu \mathrm{m}$ nylon membrane filters. The equilibrium $\mathrm{pH}$ was determined, and the concentrations of $\mathrm{Pb}, \mathrm{Cd}, \mathrm{Zn}$ and $\mathrm{Cu}$ in the filtrates were measured by ICP-OES. In this experiment, there were three replicates in each treatment.

Extractability of $\mathrm{Pb}, \mathrm{Cd}, \mathrm{Zn}$ and $\mathrm{Cu}$ in mine soils by citric acid and oxalic acid as a function of $\mathrm{pH}$

Many plants can produce organic acids and protons from root exudation or litter degradation. Citric and oxalic acids were chosen to study the combined effects of $\mathrm{pH}$ and organic acids on heavy metal extraction because they have the highest chelating abilities with heavy metals according to the results of the above experiment. A total of $1.5 \mathrm{~g}$ soil was placed in a $50-\mathrm{mL}$ polypropylene centrifuge tube, $30 \mathrm{~mL}$ organic

Table 2 Extraction of $\mathrm{Pb}, \mathrm{Cd}, \mathrm{Zn}$ and $\mathrm{Cu}\left(\mathrm{mg} \mathrm{kg}^{-1}\right)$ from Chenzhou soil by organic acids at initial $\mathrm{pH} 7$

\begin{tabular}{|c|c|c|c|c|c|c|c|c|}
\hline \multirow[t]{2}{*}{ Organic acids } & \multirow{2}{*}{$\begin{array}{l}\text { Heavy } \\
\text { metals }\end{array}$} & \multicolumn{7}{|c|}{ Concentrations of organic acids $\left(\mathrm{mmol} \mathrm{L}^{-1}\right)$} \\
\hline & & 0 & 0.2 & 0.5 & 1.0 & 2.0 & 5.0 & 10.0 \\
\hline \multirow{2}{*}{$\begin{array}{l}\text { Acetic/Fumaric } \\
\text { acid }\end{array}$} & $\mathrm{Pb} / \mathrm{Cd} / \mathrm{Zn}$ & $\mathrm{nd}^{\mathrm{a}}$ & nd & nd & nd & nd & nd & nd \\
\hline & $\mathrm{Cu}$ & $0.20 \pm 0.01 \mathrm{a}^{\mathrm{b}}$ & $0.20 \pm 0.01 \mathrm{a}$ & $0.20 \pm 0.01 \mathrm{a}$ & $0.20 \pm 0.01 \mathrm{a}$ & $0.20 \pm 0.01 \mathrm{a}$ & $0.20 \pm 0.01 \mathrm{a}$ & $0.20 \pm 0.01 \mathrm{a}$ \\
\hline \multirow[t]{2}{*}{ Oxalic acid } & $\mathrm{Pb} / \mathrm{Cd} / \mathrm{Zn}$ & nd & nd & nd & nd & nd & nd & nd \\
\hline & $\mathrm{Cu}$ & $0.20 \pm 0.01 \mathrm{c}$ & $0.23 \pm 0.04 c$ & $0.25 \pm 0.05 c$ & $0.24 \pm 0.05 c$ & $0.31 \pm 0.03 c$ & $2.42 \pm 0.01 b$ & $12.5 \pm 0.21 \mathrm{a}$ \\
\hline \multirow[t]{2}{*}{ Tartaric acid } & $\mathrm{Pb} / \mathrm{Cd} / \mathrm{Zn}$ & nd & nd & nd & nd & nd & nd & nd \\
\hline & $\mathrm{Cu}$ & $0.20 \pm 0.01 \mathrm{e}$ & $0.22 \pm 0.03 \mathrm{e}$ & $0.22 \pm 0.02 \mathrm{e}$ & $0.31 \pm 0.03 \mathrm{~d}$ & $0.44 \pm 0.02 c$ & $1.09 \pm 0.03 b$ & $2.19 \pm 0.01 \mathrm{a}$ \\
\hline \multirow[t]{3}{*}{ Malic acid } & $\mathrm{Pb} / \mathrm{Cd}$ & nd & nd & nd & nd & nd & nd & nd \\
\hline & $\mathrm{Zn}$ & nd & nd & nd & nd & nd & nd & $0.67 \pm 0.13$ \\
\hline & $\mathrm{Cu}$ & $0.20 \pm 0.01 \mathrm{e}$ & $0.21 \pm 0.01 \mathrm{e}$ & $0.33 \pm 0.01 \mathrm{e}$ & $0.69 \pm 0.01 d$ & $1.59 \pm 0.07 \mathrm{c}$ & $3.48 \pm 0.12 b$ & $8.41 \pm 0.34 \mathrm{a}$ \\
\hline \multirow[t]{4}{*}{ Citric acid } & $\mathrm{Pb}$ & nd & nd & nd & nd & nd & $7.79 \pm 1.19 b$ & $47.1 \pm 3.20 \mathrm{a}$ \\
\hline & $\mathrm{Cd}$ & nd & nd & nd & nd & $0.74 \pm 0.05 \mathrm{c}$ & $4.20 \pm 0.03 b$ & $9.19 \pm 0.21 \mathrm{a}$ \\
\hline & $\mathrm{Zn}$ & nd & nd & nd & $0.51 \pm 0.25 \mathrm{~d}$ & $7.95 \pm 0.17 \mathrm{c}$ & $47.1 \pm 1.34 b$ & $102 \pm 3.78 \mathrm{a}$ \\
\hline & $\mathrm{Cu}$ & $0.20 \pm 0.01 \mathrm{f}$ & $0.61 \pm 0.04 \mathrm{f}$ & $4.69 \pm 0.18 \mathrm{e}$ & $21.2 \pm 0.65 \mathrm{~d}$ & $67.0 \pm 0.82 \mathrm{c}$ & $149 \pm 3.02 b$ & $204 \pm 1.71 \mathrm{a}$ \\
\hline
\end{tabular}

${ }^{\mathrm{a}}$ nd $=$ not detected $;{ }^{\mathrm{b}}$ values $\pm \mathrm{SD}(n=3)$, means in the same row followed by the same letters are not significantly different, whereas means by the different letters are significantly different at $p<0.05$ 
acid (citric acid or oxalic acid) solution containing $0.01 \mathrm{~mol} \mathrm{~L}^{-1} \mathrm{NaNO}_{3}$ was added, and then 2 drops of toluene was added. The tested concentration of citric acid and oxalic acid was $0,0.5,1.0$ and $5.0 \mathrm{mmol} \mathrm{L}^{-1}$, respectively, and their solution $\mathrm{pH}$ was adjusted to different values using diluted $\mathrm{NaOH} / \mathrm{HNO}_{3}$. The subsequent procedure was the same as described above. Finally, the equilibrium $\mathrm{pH}$ was determined, and the concentrations of $\mathrm{Pb}, \mathrm{Cd}, \mathrm{Zn}$ or $\mathrm{Cu}$ in the filtrates were measured by ICP-OES. In this experiment, there were three replicates in each treatment.

\section{Statistical analysis}

The statistical analysis was performed in triplicate samples, and the mean values with standard error were recorded. The data were subjected to one-way analysis of variance (ANOVA) and Duncan's multiple range test using SPSS (version 16.0, SPSS Inc., USA). The significant differences between treatments were calculated at $5 \%$ probability levels $(p<0.05)$.

\section{Results and discussion}

Extractability of heavy metals in mine soils by different organic acids

The extraction of heavy metals from both mine soils varied greatly (Tables 2, 3). Except citric acid with higher concentration, organic acids hardly extracted heavy metals from Chenzhou soil. Contrarily, all organic acids could extract well heavy metals from Daxin soil. The heavy metals of Daxin soil were much easily extracted than that of Chenzhou soil. Soil properties such as pH, CEC, OM, clay content and oxides of iron and manganese play important roles in controlling the solubility of heavy metals (Naidu et al. 1994). Chenzhou soil was a permanent charge soil with high surface negative charges, so its soil characteristics dominantly control the solubility of heavy metal solubility, and the extraction of heavy metals was hardly affected by environmental factors such as organic acids. On the contrary, Daxin soil was a variable charge soil where the charge could be regulated by the adsorption of

Table 3 Extraction of $\mathrm{Pb}, \mathrm{Cd}, \mathrm{Zn}$ and $\mathrm{Cu}\left(\mathrm{mg} \mathrm{kg}^{-1}\right)$ from Daxin soil by organic acids at initial $\mathrm{pH} 7$

\begin{tabular}{|c|c|c|c|c|c|c|c|c|}
\hline \multirow{2}{*}{$\begin{array}{l}\text { Organic } \\
\text { acids }\end{array}$} & \multirow{2}{*}{$\begin{array}{l}\text { Heavy } \\
\text { metals }\end{array}$} & \multicolumn{7}{|c|}{ Concentrations of organic acids $\left(\mathrm{mmol} \mathrm{L}^{-1}\right)$} \\
\hline & & 0 & 0.2 & 0.5 & 1.0 & 2.0 & 5.0 & 10.0 \\
\hline \multirow[t]{4}{*}{ Acetic acid } & $\mathrm{Pb}$ & $1.17 \pm 0.22 \mathrm{~cd}^{\mathrm{a}}$ & $0.99 \pm 0.01 \mathrm{e}$ & $1.14 \pm 0.08 \mathrm{~d}$ & $1.09 \pm 0.02 \mathrm{de}$ & $1.27 \pm 0.07 \mathrm{c}$ & $1.53 \pm 0.10 \mathrm{~b}$ & $2.27 \pm 0.02 \mathrm{a}$ \\
\hline & $\mathrm{Cd}$ & $2.46 \pm 0.02 \mathrm{c}$ & $2.66 \pm 0.16 b$ & $2.69 \pm 0.03 b$ & $2.66 \pm 0.01 b$ & $2.76 \pm 0.14 b$ & $2.76 \pm 0.06 b$ & $2.95 \pm 0.31 \mathrm{a}$ \\
\hline & $\mathrm{Zn}$ & $202 \pm 0.71 \mathrm{a}$ & $204 \pm 1.10 \mathrm{a}$ & $202 \pm 2.78 \mathrm{a}$ & $206 \pm 1.56 \mathrm{a}$ & $206 \pm 11.8 \mathrm{a}$ & $199 \pm 4.61 \mathrm{a}$ & $203 \pm 2.46 \mathrm{a}$ \\
\hline & $\mathrm{Cu}$ & $0.44 \pm 0.00 \mathrm{~d}$ & $0.47 \pm 0.01 \mathrm{~cd}$ & $0.50 \pm 0.01 \mathrm{bc}$ & $0.52 \pm 0.01 b$ & $0.52 \pm 0.01 b$ & $0.53 \pm 0.01 b$ & $0.77 \pm 0.09 \mathrm{a}$ \\
\hline \multirow{4}{*}{$\begin{array}{c}\text { Fumaric } \\
\text { acid }\end{array}$} & $\mathrm{Pb}$ & $1.17 \pm 0.22 \mathrm{e}$ & $1.11 \pm 0.04 \mathrm{e}$ & $1.23 \pm 0.06 \mathrm{e}$ & $1.46 \pm 0.10 \mathrm{~d}$ & $1.76 \pm 0.04 \mathrm{c}$ & $2.69 \pm 0.04 b$ & $3.86 \pm 0.14 a$ \\
\hline & $\mathrm{Cd}$ & $2.46 \pm 0.02 \mathrm{f}$ & $2.82 \pm 0.04 \mathrm{e}$ & $2.87 \pm 0.05 \mathrm{e}$ & $3.04 \pm 0.02 \mathrm{~d}$ & $3.22 \pm 0.02 \mathrm{c}$ & $3.76 \pm 0.08 b$ & $4.55 \pm 0.07 a$ \\
\hline & $\mathrm{Zn}$ & $202 \pm 0.71 d$ & $230 \pm 2.12 \mathrm{c}$ & $225 \pm 5.37 \mathrm{c}$ & $226 \pm 4.95 c$ & $231 \pm 1.56 \mathrm{c}$ & $251 \pm 8.21 b$ & $274 \pm 4.95 \mathrm{a}$ \\
\hline & $\mathrm{Cu}$ & $0.44 \pm 0.00 \mathrm{f}$ & $0.43 \pm 0.00 \mathrm{f}$ & $0.49 \pm 0.02 \mathrm{e}$ & $0.48 \pm 0.01 \mathrm{e}$ & $0.56 \pm 0.02 \mathrm{c}$ & $0.68 \pm 0.04 b$ & $0.87 \pm 0.01 \mathrm{a}$ \\
\hline \multirow[t]{4}{*}{ Oxalic acid } & $\mathrm{Pb}$ & $1.17 \pm 0.22 \mathrm{~g}$ & $2.20 \pm 0.03 f$ & $4.42 \pm 0.06 \mathrm{e}$ & $7.32 \pm 0.05 \mathrm{~d}$ & $9.74 \pm 0.10 \mathrm{c}$ & $14.8 \pm 2.10 \mathrm{~b}$ & $21.0 \pm 0.09 \mathrm{a}$ \\
\hline & $\mathrm{Cd}$ & $2.46 \pm 0.02 \mathrm{a}$ & $1.98 \pm 0.03 b$ & $1.62 \pm 0.03 c$ & $1.49 \pm 0.03 \mathrm{~d}$ & $1.14 \pm 0.03 \mathrm{f}$ & $1.05 \pm 0.03 \mathrm{~g}$ & $1.23 \pm 0.01 \mathrm{e}$ \\
\hline & $\mathrm{Zn}$ & $202 \pm 0.71 \mathrm{~g}$ & $242 \pm 0.35 f$ & $327 \pm 4.24 \mathrm{e}$ & $432 \pm 10.2 d$ & $484 \pm 18.3 c$ & $589 \pm 10.2 b$ & $741 \pm 20.3 a$ \\
\hline & $\mathrm{Cu}$ & $0.44 \pm 0.00 \mathrm{~g}$ & $0.64 \pm 0.01 \mathrm{f}$ & $1.26 \pm 0.00 \mathrm{e}$ & $2.34 \pm 0.04 d$ & $4.48 \pm 0.33 c$ & $7.41 \pm 0.10 \mathrm{~b}$ & $10.1 \pm 0.11 \mathrm{a}$ \\
\hline \multirow{4}{*}{$\begin{array}{l}\text { Tartaric } \\
\text { acid }\end{array}$} & $\mathrm{Pb}$ & $1.17 \pm 0.22 \mathrm{f}$ & $1.13 \pm 0.04 \mathrm{f}$ & $1.55 \pm 0.06 \mathrm{~d}$ & $2.42 \pm 0.02 \mathrm{c}$ & $3.61 \pm 0.21 \mathrm{c}$ & $9.51 \pm 0.04 b$ & $21.4 \pm 1.26 a$ \\
\hline & $\mathrm{Cd}$ & $2.46 \pm 0.02 \mathrm{a}$ & $2.30 \pm 0.02 b$ & $2.08 \pm 0.06 \mathrm{c}$ & $1.92 \pm 0.01 \mathrm{e}$ & $1.76 \pm 0.03 f$ & $1.75 \pm 0.04 \mathrm{f}$ & $1.98 \pm 0.01 \mathrm{~d}$ \\
\hline & $\mathrm{Zn}$ & $202 \pm 0.71 d$ & $184 \pm 7.34 \mathrm{f}$ & $192 \pm 1.16 \mathrm{ef}$ & $199 \pm 0.95 \mathrm{de}$ & $234 \pm 12.4 \mathrm{c}$ & $319 \pm 2.69 b$ & $383 \pm 15.0 \mathrm{a}$ \\
\hline & $\mathrm{Cu}$ & $0.44 \pm 0.00 \mathrm{~d}$ & $0.54 \pm 0.00 \mathrm{~d}$ & $0.54 \pm 0.01 \mathrm{~d}$ & $0.59 \pm 0.00 \mathrm{~d}$ & $0.81 \pm 0.19 \mathrm{c}$ & $1.13 \pm 0.17 b$ & $1.90 \pm 0.26 \mathrm{a}$ \\
\hline \multirow[t]{4}{*}{ Malic acid } & $\mathrm{Pb}$ & $1.17 \pm 0.22 \mathrm{f}$ & $1.26 \pm 0.02 \mathrm{f}$ & $2.35 \pm 0.03 \mathrm{e}$ & $5.47 \pm 0.05 \mathrm{~d}$ & $7.21 \pm 0.07 \mathrm{c}$ & $12.6 \pm 0.11 b$ & $18.3 \pm 0.07 \mathrm{a}$ \\
\hline & $\mathrm{Cd}$ & $2.46 \pm 0.02 \mathrm{a}$ & $2.25 \pm 0.03 b$ & $1.95 \pm 0.04 \mathrm{c}$ & $1.64 \pm 0.03 \mathrm{~d}$ & $1.47 \pm 0.03 f$ & $1.39 \pm 0.02 \mathrm{f}$ & $1.42 \pm 0.02 \mathrm{f}$ \\
\hline & $\mathrm{Zn}$ & $202 \pm 0.71 \mathrm{~g}$ & $223 \pm 0.05 \mathrm{f}$ & $265 \pm 1.12 \mathrm{e}$ & $286 \pm 0.82 \mathrm{~d}$ & $337 \pm 9.51 \mathrm{c}$ & $426 \pm 6.89 b$ & $532 \pm 10.5 a$ \\
\hline & $\mathrm{Cu}$ & $0.44 \pm 0.00 \mathrm{f}$ & $0.59 \pm 0.03 f$ & $0.92 \pm 0.23 \mathrm{e}$ & $1.32 \pm 0.15 \mathrm{~d}$ & $2.63 \pm 0.37 \mathrm{c}$ & $4.78 \pm 0.12 b$ & $6.45 \pm 0.32 \mathrm{a}$ \\
\hline \multirow[t]{4}{*}{ Citric acid } & $\mathrm{Pb}$ & $1.17 \pm 0.22 \mathrm{f}$ & $4.39 \pm 0.08 \mathrm{f}$ & $15.1 \pm 0.35 \mathrm{e}$ & $38.0 \pm 0.02 \mathrm{~d}$ & $77.3 \pm 1.77 \mathrm{c}$ & $120 \pm 7.09 b$ & $177 \pm 2.40 \mathrm{a}$ \\
\hline & $\mathrm{Cd}$ & $2.46 \pm 0.02 \mathrm{f}$ & $2.17 \pm 0.01 \mathrm{f}$ & $3.88 \pm 0.07 \mathrm{e}$ & $6.45 \pm 0.16 \mathrm{~d}$ & $9.88 \pm 0.40 \mathrm{c}$ & $12.8 \pm 0.74 b$ & $16.2 \pm 0.25 \mathrm{a}$ \\
\hline & $\mathrm{Zn}$ & $202 \pm 0.71 \mathrm{f}$ & $219 \pm 3.68 \mathrm{f}$ & $349 \pm 8.85 \mathrm{e}$ & $604 \pm 15.4 d$ & $820 \pm 16.9 c$ & $971 \pm 50.1 b$ & $1,091 \pm 59.7 \mathrm{a}$ \\
\hline & $\mathrm{Cu}$ & $0.44 \pm 0.00 \mathrm{~g}$ & $1.60 \pm 0.02 \mathrm{f}$ & $2.91 \pm 0.20 \mathrm{e}$ & $3.36 \pm 0.17 \mathrm{~d}$ & $4.86 \pm 0.15 c$ & $6.44 \pm 0.29 b$ & $8.27 \pm 0.71 \mathrm{a}$ \\
\hline
\end{tabular}

${ }^{\text {a }}$ Values $\pm \mathrm{SD}(n=3)$, means in the same row followed by the same letters are not significantly different, whereas means by the different letters are significantly different at $p<0.05$ 
potential-determining ions $\left(\mathrm{H}^{+}\right.$and $\left.\mathrm{OH}^{-}\right)$on the surface. Subsequently, the adsorption of heavy metal ions on Daxin soils was easily affected by environmental factors such as chelating organic acids.

Different organic acids showed different influences on the solubility of heavy metals in both mine soils (Tables 2, 3). For example, the extraction amounts of $\mathrm{Cu}$ from the Chenzhou soil by acetic acid, fumaric acid, oxalic acid, malic acid, tartaric acid and citric acid at a concentration of $10.0 \mathrm{mmol} \mathrm{L}^{-1}$ were $0.20,0.20,12.5$, $2.19,8.41$ and $204 \mathrm{mg} \mathrm{kg}^{-1}$, respectively, whereas from the Daxin soil, the values were $0.77,0.87,10.1,6.45$, 1.90 and $8.27 \mathrm{mg} \mathrm{kg}^{-1}$, respectively. Elkhatib et al. (2007) also found that citric acid had higher $\mathrm{Cu}$ extraction ability than other organic acids. The $\mathrm{Zn}$ extraction amounts from the Daxin soil by these organic acids were 203, 274, 741, 383, 532 and $1,091 \mathrm{mg} \mathrm{kg}^{-1}$, respectively, while from the Chenzhou soil, only a small quantity of $\mathrm{Zn}$ was extracted by citric acid. So, citric acid had the strongest ability to extract heavy metals, followed by oxalic acid.

In the presence of citric acid of $10.0 \mathrm{mmol} \mathrm{L}^{-1}$, the desorption rate of metals from Daxin soil followed the order: $\mathrm{Pb}(21.3 \%)<\mathrm{Zn}(26.4 \%)<\mathrm{Cu}(28.3 \%)<\mathrm{Cd}$ $(35.3 \%)$ and that from Chenzhou soil followed the same order: $\mathrm{Pb}(0.7 \%)<\mathrm{Zn}(4.1 \%)<\mathrm{Cu}(10.1 \%)<\mathrm{Cd}$ $(11.9 \%)$. However, the common sequence of metal adsorption on soils is $\mathrm{Pb}>\mathrm{Cu}>\mathrm{Zn}>\mathrm{Cd}$, which it is related to the first hydrolysis equilibrium constant (Usman 2008). In the absence of citric acid, the desorption rate of heavy metals from Daxin soil followed the order: $\mathrm{Pb}$ $(0.14 \%) \quad<\mathrm{Cu} \quad(1.5 \%) \quad<\mathrm{Zn} \quad(4.9 \%) \quad<\mathrm{Cd} \quad(5.4 \%)$.
Apparently, citric acid changed the desorption orders of $\mathrm{Cu}$ and $\mathrm{Zn}$ in both mine soils, which could be attributed to higher stability constant of $\mathrm{Cu}$-citric acid complex than $\mathrm{Zn}$-citric acid complex. Furthermore, for most metals, citric acid has the strongest chelating ability among low molecular weight organic acids.

Citric acid has the strongest ability to extract heavy metals because it has three carboxyl groups, which can form stable five- or six-member chelate rings (Qin et al. 2004). However, $\mathrm{Cu}$ extraction from Daxin soil by citric acid with higher concentration was less than that by oxalic acid under the same conditions (Table 3), perhaps because the equilibrium $\mathrm{pH}$ of soil citric acid was higher than that of soil oxalic acid, as shown in Table 4. Equilibrium $\mathrm{pH}$ plays another important role in controlling the solubility of heavy metals (Appel and Ma 2002). The acid-buffering capacity of mine soils had different response to organic acids (Table 4). The values of equilibrium $\mathrm{pH}$ of Daxin soil ranged from 5.77 to 7.23 when different organic acids with initial $\mathrm{pH} 7$ were added, whereas that of Chenzhou soil ranged from 8.06 to 9.43 , that is, Chenzhou soil had greater acid-buffering capacity than Daxin soil. This partly explained why the extraction of heavy metals from the former was much lower than that from the latter. Additionally, the different equilibrium pHs of the Daxin soil may partly explain why the extraction amounts of $\mathrm{Cd}$ decreased as the concentration of some organic acids (oxalic, tartaric and malic acid) increased (Table 3). Herein, it is necessary to consider the interaction effect of organic acids and $\mathrm{pH}$ on the extractability of heavy metals in mine soils.

Table 4 Equilibrium $\mathrm{pH}$ values after organic acids added to mine soils with initial $\mathrm{pH} 7$

\begin{tabular}{|c|c|c|c|c|c|c|c|c|}
\hline \multirow[t]{2}{*}{ Soils } & \multirow[t]{2}{*}{ Organic acids } & \multicolumn{7}{|c|}{ Concentrations of organic acids added to the soils $\left(\mathrm{mmol} \mathrm{L}^{-1}\right)$} \\
\hline & & 0 & 0.2 & 0.5 & 1.0 & 2.0 & 5.0 & 10.0 \\
\hline \multirow[t]{6}{*}{ Chenzhou soil } & Acetic acid & $8.44 \pm 0.02^{\mathrm{a}}$ & $8.14 \pm 0.01$ & $8.15 \pm 0.01$ & $8.19 \pm 0.01$ & $8.21 \pm 0.01$ & $8.12 \pm 0.00$ & $7.97 \pm 0.03$ \\
\hline & Fumaric acid & $8.44 \pm 0.02$ & $8.45 \pm 0.03$ & $8.47 \pm 0.02$ & $8.48 \pm 0.03$ & $8.51 \pm 0.02$ & $8.53 \pm 0.02$ & $8.55 \pm 0.03$ \\
\hline & Oxalic acid & $8.44 \pm 0.02$ & $8.53 \pm 0.01$ & $8.66 \pm 0.01$ & $8.88 \pm 0.01$ & $9.18 \pm 0.02$ & $9.35 \pm 0.01$ & $9.43 \pm 0.03$ \\
\hline & Tartaric acid & $8.44 \pm 0.02$ & $8.47 \pm 0.01$ & $8.51 \pm 0.01$ & $8.51 \pm 0.02$ & $8.48 \pm 0.02$ & $8.53 \pm 0.01$ & $8.55 \pm 0.01$ \\
\hline & Malic acid & $8.44 \pm 0.02$ & $8.06 \pm 0.02$ & $8.14 \pm 0.03$ & $8.24 \pm 0.01$ & $8.27 \pm 0.01$ & $8.36 \pm 0.04$ & $8.40 \pm 0.03$ \\
\hline & Citric acid & $8.44 \pm 0.02$ & $8.31 \pm 0.02$ & $8.40 \pm 0.01$ & $8.62 \pm 0.02$ & $8.79 \pm 0.02$ & $8.85 \pm 0.02$ & $8.90 \pm 0.02$ \\
\hline \multirow[t]{6}{*}{ Daxin soil } & Acetic acid & $5.77 \pm 0.02$ & $5.84 \pm 0.01$ & $5.86 \pm 0.01$ & $5.90 \pm 0.01$ & $6.02 \pm 0.00$ & $6.07 \pm 0.01$ & $6.24 \pm 0.00$ \\
\hline & Fumaric acid & $5.77 \pm 0.02$ & $5.87 \pm 0.01$ & $5.92 \pm 0.01$ & $5.91 \pm 0.02$ & $5.98 \pm 0.04$ & $6.04 \pm 0.02$ & $6.11 \pm 0.01$ \\
\hline & Oxalic acid & $5.77 \pm 0.02$ & $5.87 \pm 0.01$ & $6.03 \pm 0.05$ & $6.14 \pm 0.02$ & $6.46 \pm 0.06$ & $6.70 \pm 0.02$ & $7.00 \pm 0.05$ \\
\hline & Tartaric acid & $5.77 \pm 0.02$ & $5.87 \pm 0.01$ & $5.96 \pm 0.01$ & $5.99 \pm 0.03$ & $6.02 \pm 0.04$ & $6.11 \pm 0.02$ & $6.26 \pm 0.01$ \\
\hline & Malic acid & $5.77 \pm 0.02$ & $5.87 \pm 0.01$ & $5.99 \pm 0.02$ & $6.07 \pm 0.02$ & $6.21 \pm 0.03$ & $6.56 \pm 0.02$ & $6.89 \pm 0.03$ \\
\hline & Citric acid & $5.77 \pm 0.02$ & $5.90 \pm 0.04$ & $6.12 \pm 0.03$ & $6.30 \pm 0.03$ & $6.70 \pm 0.07$ & $7.07 \pm 0.03$ & $7.23 \pm 0.01$ \\
\hline
\end{tabular}

\footnotetext{
${ }^{\mathrm{a}}$ Values $\pm \mathrm{SD}(n=3)$
} 

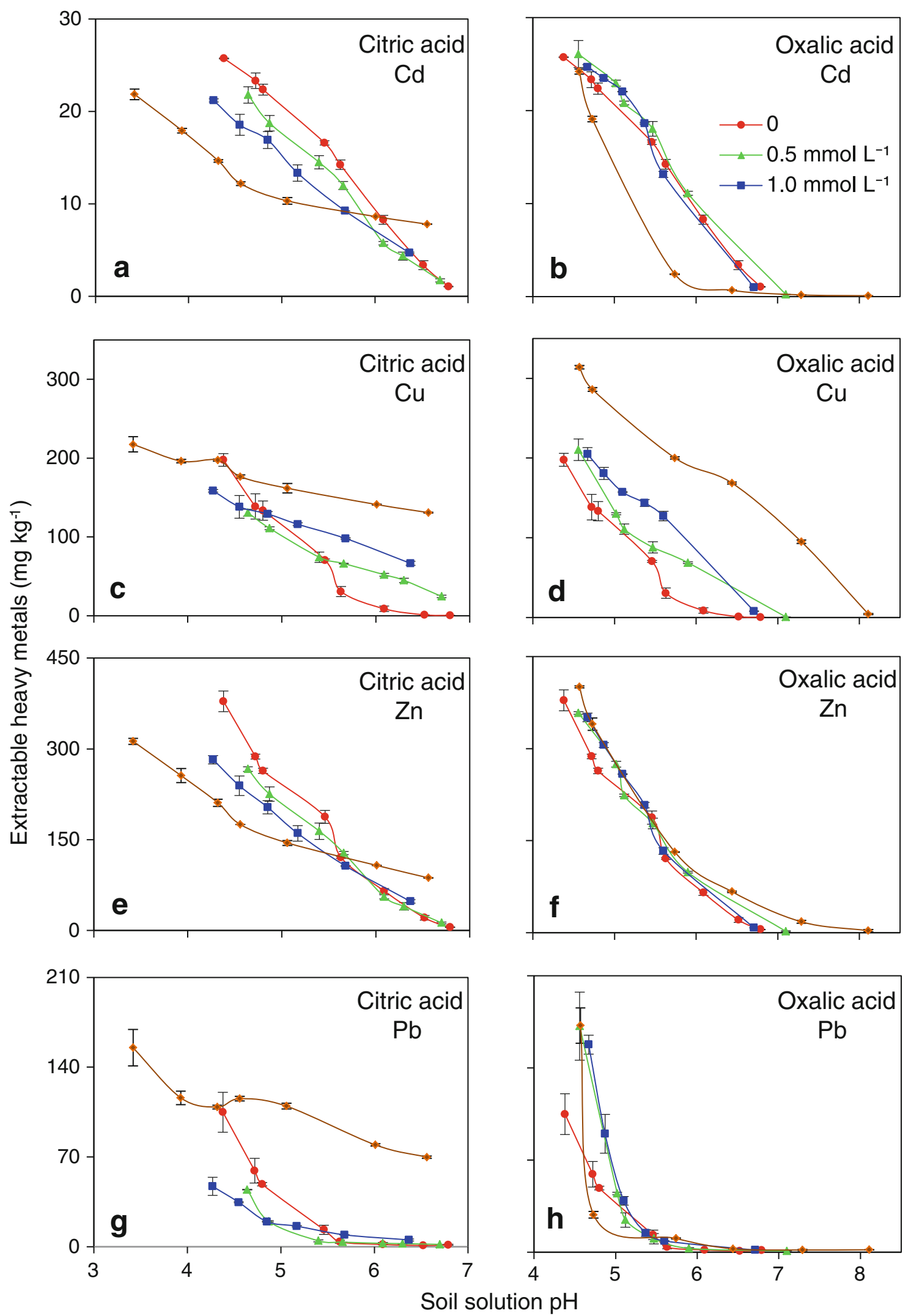

Fig. 1 Extraction of $\mathrm{Pb}, \mathrm{Cd}, \mathrm{Zn}$ and $\mathrm{Cu}$ from Chenzhou soil by citric acid and oxalic acid as a function of pH. Error bars represent standard deviations of triplicate measurements 

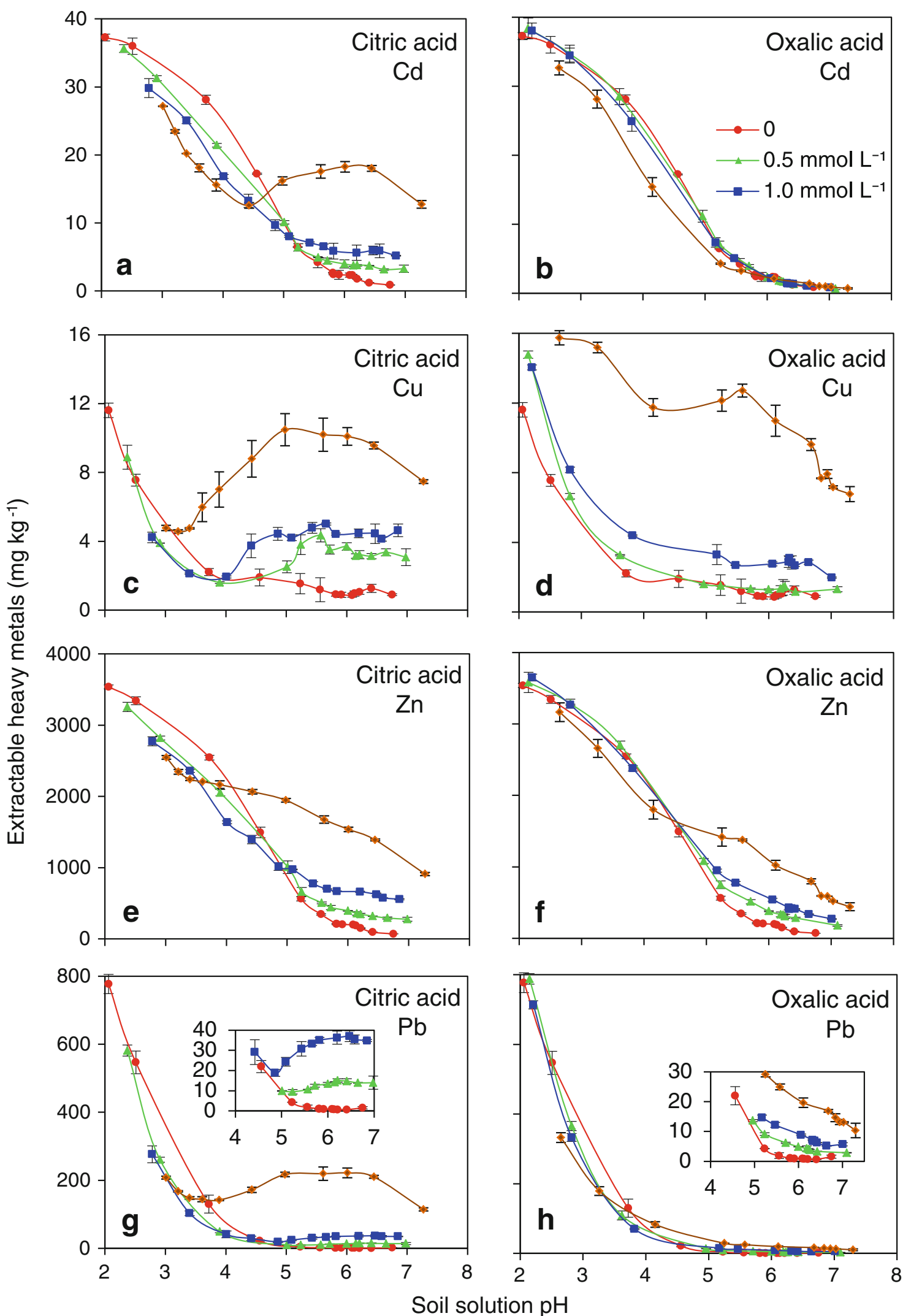

Fig. 2 Extraction of $\mathrm{Pb}, \mathrm{Cd}, \mathrm{Zn}$ and $\mathrm{Cu}$ from Daxin soil by citric acid and oxalic acid as a function of $\mathrm{pH}$. Error bars represent standard deviations of triplicate measurements 
Extractability of heavy metals in mine soils by organic acids as a function of $\mathrm{pH}$

The extraction amount of heavy metals significantly decreased with increasing $\mathrm{pH}$ (Figs. 1 and 2). In the absence of organic acids, for Chenzhou soil, when equilibrium $\mathrm{pH}$ increased from 4.4 to 6.8 , the extraction of heavy metals decreased as follows: $\mathrm{Cd}$ from 25.7 to $1.04 \mathrm{mg} \mathrm{kg}^{-1}, \mathrm{Cu}$ from 198 to $0.34 \mathrm{mg} \mathrm{kg}^{-1}, \mathrm{Zn}$ from 379 to $5.44 \mathrm{mg} \mathrm{kg}^{-1}$ and $\mathrm{Pb}$ from 105 to $1.50 \mathrm{mg} \mathrm{kg}^{-1}$. For Daxin soil, when $\mathrm{pH}$ increased from 2.1 to 6.8 , the corresponding decrease was: $\mathrm{Cd}$ from 37.3 to $0.88 \mathrm{mg} \mathrm{kg}^{-1}, \mathrm{Cu}$ from 11.6 to $0.90 \mathrm{mg} \mathrm{kg}^{-1}, \mathrm{Zn}$ from 3,538 to $80.0 \mathrm{mg} \mathrm{kg}^{-1}$ and $\mathrm{Pb}$ from 777 to $1.56 \mathrm{mg} \mathrm{kg}^{-1}$, respectively. The dependency of heavy metals on soil $\mathrm{pH}$ was consistent with the results obtained by some previous researchers (Appel and $\mathrm{Ma}$ 2002; Qin et al. 2004). The net negative surface charge of soils increases with increasing $\mathrm{pH}$, resulting in higher affinity between soil surfaces and heavy metal ions (Harter and Naidu 2001). Further, pH changes the ion forms of metals adsorbed on soil surfaces where the hydrolysis of metal cations increases with increasing $\mathrm{pH}$. In addition, soil $\mathrm{pH}$ also affects the solubility of heavy metals by influencing the surface potential, clay edge charge, ion-pair formation, the solubility of organic matter and the stability of metal carbonates and phosphates (Appel and Ma 2002). In a word, due to these changes of heavy metals in adsorption, solubility, stability, etc., the extractability of heavy metals was affected strongly by soil $\mathrm{pH}$, in which there is usually marked decrease in the extraction of heavy metals with the increase in soil $\mathrm{pH}$.

In the presence of organic acids, the extraction of heavy metals from mine soils also decreased with increasing $\mathrm{pH}$ (Figs. 1, 2). However, for Daxin soil, the extraction of $\mathrm{Cd}$, $\mathrm{Cu}$ and $\mathrm{Pb}$ by citric acid had different trend with increasing $\mathrm{pH}$, where the extraction amounts decreased sharply at first, then increased dramatically and then declined significantly again (Fig. 2). Ding et al. (2008) also found the similar behavior for $\mathrm{Cd}$ on red soil and paddy soil. The main form of citric acid (denoted as $\mathrm{H}_{3} \mathrm{~L}$ ) changed from $\mathrm{H}_{3} \mathrm{~L}$ to $\mathrm{H}_{2} \mathrm{~L}^{-}$to $\mathrm{HL}^{2-}$ and finally to $\mathrm{L}^{3-}$ with the increase in soil $\mathrm{pH}$. Because the latter two forms had higher chelating ability to heavy metals and restricted stronger the hydrolysis of heavy metals than other formers, there was more extraction of heavy metals at higher $\mathrm{pH}$ (Qin et al. 2004). For Chenzhou soil, the extraction of heavy metals continually decreased with increasing pH (Fig. 1), it could be explained that there had higher affinity to heavy metals and soil $\mathrm{pH}$ played dominant role in controlling the solubility of heavy metals.

Different concentrations $\left(0-5 \mathrm{mmol} \mathrm{L}^{-1}\right)$ of citric acid or oxalic acid exerted different effects on heavy metal solubility, depending on the soil solution $\mathrm{pH}$ and the specific organic acid. For example, citric acid promoted $\mathrm{Cd}$ adsorption at low $\mathrm{pH}$, whereas it enhanced $\mathrm{Cd}$ desorption at high $\mathrm{pH}$; oxalic acid had little effect except it enhanced $\mathrm{Cd}$ adsorption at high concentration $\left(5 \mathrm{mmol} \mathrm{L}{ }^{-1}\right)$. Some previous researchers (Naidu and Harter 1998; Ding et al. 2008) also found that $\mathrm{Cd}$ adsorption was enhanced in the presence of organic ligands at low $\mathrm{pH}$. However, other studies have shown that $\mathrm{Cd}$ extraction increased with an increase in citrate concentration (Gao et al. 2003; Hu et al. 2006). Copper extraction increased as the concentration of citric or oxalic acid increased, indicating that dissolved citric and oxalic acids compete over soil adsorption sites for $\mathrm{Cu}$. For $\mathrm{Zn}$, the effect of citric acid was similar to $\mathrm{Cd}$, whereas that of oxalic acid differed between both soils. The oxalic acid had similar effects as citric acid on the Daxin soil but had little effect on the Chenzhou soil. For $\mathrm{Pb}$, the citric and oxalic acid enhanced desorption on the Daxin soil. In the Chenzhou soil, $\mathrm{Pb}$ was little affected by organic acids, but the strong complexing ligand, citrate, reduced $\mathrm{Pb}$ sorption at a high concentration (5.0 mmol L $\left.{ }^{-1}\right)$. Overall, citric acid and oxalic acid could increase the leaching risk of heavy metals at high $\mathrm{pH}$, whereas only oxalic acid could increase $\mathrm{Cu}$ leaching at low $\mathrm{pH}$.

With the introduction of organic acids, the solubility of heavy metals could be changed due to the interaction among soil surfaces, soil solution $\mathrm{pH}$, organic ligands and heavy metals. On the one hand, organic acids enhanced the mobility of heavy metals by forming stable metal-ligand complexes, or by directly competing for cation adsorption sites or by reducing the negative electrostatic potential of soil surfaces (Collins et al. 2003). On the other hand, organic acids could also decreased the mobility of heavy metals by co-adsorbing on soil surfaces and forming soil organic acid-metal bridge (ternary) complexes (Naidu and Harter 1998). In short, the effect of organic acids on the solubility of heavy metals in soils is not simple or constant. For example, in this study, organic acids at low concentration can extract more heavy metals than at high concentration in some cases (Figs. 1, 2), and weak organic acids can extract more heavy metals than strong organic acids (Fig. 2c, d). Therefore, more researches should be focused on the interaction among soils, organic acids, heavy metals and soil solution $\mathrm{pH}$. 


\section{Conclusion}

The effects of different organic acids on the extraction of $\mathrm{Pb}, \mathrm{Cd}, \mathrm{Zn}$ and $\mathrm{Cu}$ from an alkaline mine soil and an acid mine soil were conducted. Under alkaline conditions, citric acid could extract some heavy metals with high concentrations. Under acidic conditions, the extraction of heavy metals from both soils decreased with increasing $\mathrm{pH}$. Citric and oxalic acids increased the risk of leaching of heavy metals at high $\mathrm{pH}$, whereas at low $\mathrm{pH}$, only oxalic acid increased $\mathrm{Cu}$ leaching. The risk of heavy metals leaching from the Daxin soil was higher than that from the Chenzhou soil, which had a higher acidic buffering capacity than the Daxin soil. The results indicate that the effects of organic acids on heavy metal dissolution depend on soil properties, the types of heavy metals, organic acids (types and concentrations) and the $\mathrm{pH}$ of the rhizosphere. Plants that produce substantial citric acid, oxalic acid or protons from root exudation or litter degradation should be avoided in the vegetative rehabilitation of mining sites, especially for acidic mine soils.

Acknowledgments This research was financially supported by the National Natural Science Foundation of China (No. 41101306, 41371463) and the Central Public Research Institutes Basic Funds for Research and Development (Agro-Environmental Protection Institute, Ministry of Agriculture, No. 2008-zxq-13).

\section{References}

Appel C, Ma L (2002) Concentration, pH, and surface charge effects on cadmium and lead sorption in three tropical soils. J Environ Qual 31(2):581-589

Arienzo M, Adamo P, Cozzolino V (2004) The potential of Lolium perenne for revegetation of contaminated soil from a metallurgical site. Sci Total Environ 319(1-3):13-25

Bao SD (2000) Soil and agricultural chemistry analysis. China Agriculture Press, Beijing (in Chinese)

Burckhard SR, Schwab AP, Banks MK (1995) The effects of organic acids on the leaching of heavy-metals from mine tailings. J Hazard Mater 41(2-3):135-145

Collins RN, Merrington G, McLaughlin MJ, Morel JL (2003) Organic ligand and $\mathrm{pH}$ effects on isotopically exchangeable cadmium in polluted soils. Soil Sci Soc Am J 67(1):112-121

Conesa HM, Schulin R (2010) The Cartagena-La Unión mining district (SE Spain): a review of environmental problems and emerging phytoremediation solutions after fifteen years research. J Environ Monit 12(6):1225-1233

Ding YZ, Tang SR, Li ZA, Murray M (2008) Effects of low molecule weight organic acids on Cd solubility in paddy and red soils in South China. Res J Chem Environ 12(1):7-16

Elkhatib EA, Mahdy AM, Saleh ME, Barakat NH (2007) Kinetics of copper desorption from soils as affected by different organic ligands. Int J Environ Sci Tech 4(3):331-338

Gao YZ, He JZ, Ling WT, Hu HQ, Liu F (2003) Effects of organic acids on copper and cadmium desorption from contaminated soils. Environ Int 29(5):613-618
Han F, Shan XQ, Zhang SZ, Wen B, Owens G (2006) Enhanced cadmium accumulation in maize roots-the impact of organic acids. Plan Soil 289(1-2):355-368

Harter RD, Naidu R (2001) An assessment of environmental and solution parameter impact on trace-metal sorption by soils. Soil Sci Soc Am J 65(3):597-612

Hu HQ, Liu HL, He JZ, Huang QY (2006) Effect of selected organic acids on cadmium sorption by variable- and permanent-charge soils. Pedosphere 17(1):117-123

Jones DL (1998) Organic acids in the rhizosphere-a critical review. Plant Soil 205(1):25-44

Krishnamurti GSR, Cieslinski G, Huang PM, VanRees KCJ (1997) Kinetics of cadmium release from soils as influenced by organic acids: implication in cadmium availability. J Environ Qual 26(1):271-277

Lu HL, Yan CL, Liu JC (2007) Low-molecular-weight organic acids exuded by Mangrove (Kandelia candel (L.) Druce) roots and their effect on cadmium species change in the rhizosphere. Environ Exp Bot 61(2):159-166

Mendez MO, Maier RM (2008a) Phytostabilization of mine tailings in arid and semiarid environments: an emerging remediation technology. Environ Health Perspect 116(3):278-283

Mendez MO, Maier RM (2008b) Phytoremediation of mine tailings in temperate and arid environments. Rev Environ Sci Biol Technol 7(1):47-59

Naidu R, Harter RD (1998) Effect of different organic ligands on cadmium sorption by and extractability from soils. Soil Sci Soc Am J 62(3):644-650

Naidu R, Bolan NS, Kookana RS, Tiller KG (1994) Ionic-strength and $\mathrm{pH}$ effects on the sorption of cadmium and the surface charge of soils. Eur J Soil Sci 45(4):419-429

Navarro MC, Perez-Sirvent C, Martinez-Sanchez MJ, Vidal J, Tovar PJ, Bech J (2008) Abandoned mine sites as a source of contamination by heavy metals: a case study in a semi-arid zone. J Geochem Explor 96(2-3):183-193

Nelson DW, Sommers LE (1996) Total carbon, organic carbon, and organic matter. In: Sparks DL, Page AL, Helmke PA, Loeppert RH, Soluanpour PN, Tabatabai MA, Johnston CT, Sumner ME (eds) In methods of soil analysis part 3: chemical methods. Soil Science Society of America, Wisconsin

Qin F, Shan XQ, Wei B (2004) Effects of low-molecular-weight organic acids and residence time on desorption of $\mathrm{Cu}, \mathrm{Cd}$, and $\mathrm{Pb}$ from soils. Chemosphere 57(4):253-263

Qiu RL, Qiu H, Lei M, Ye ZH (2009) Advances in research on remediation of multi-metal contaminated soil in mine and surrounding area. J Agro-Environ Sci 28(6):1085-1091 (in Chinese)

Ryan PR, Delhaize E, Jones DL (2001) Function and mechanism of organic anion exudation from plant roots. Annu Rev Plant Physiol Plant Mol Biol 52:527-560

Schwab AP, Zhu DS, Banks MK (2008) Influence of organic acids on the transport of heavy metals in soil. Chemosphere 72(6):986-994

Strobel BW (2001) Influence of vegetation on low-molecular-weight carboxylic acids in soil solution-a review. Geoderma 99(3-4):169-198

Tessier A, Campbell PGC, Bisson M (1979) Sequential extraction procedure for the speciation of particulate trace metals. Anal Chem 51(7):231-235

Usman ARA (2008) The relative adsorption selectivities of $\mathrm{Pb}, \mathrm{Cu}$, $\mathrm{Zn}, \mathrm{Cd}$ and Ni by soils developed on shale in New Valley, Egypt. Geoderma 144(1-2):334-343

Vesely T, Tlustos P, Szakova J (2011) Organic salts enhanced soil risk elements leaching and bioaccumulation in Pistia stratiotes. Plant Soil Environ 57(4):166-172 
Wuana RA, Okieimen FE, Imborvungu JA (2010) Removal of heavy metals from a contaminated soil using organic chelating acids. Int J Environ Sci Tech 7(3):485-496

Zhou DM, Chen HM, Wang SQ, Zheng CR (2003) Effects of organic acids, o-Phenylenediamine and pyrocatechol on cadmium adsorption and desorption in soil. Water Air Soil Poll 145(1):109-121

Zhu D, Schwab AP, Banks MK (1999) Heavy metal leaching from mine tailings as affected by plants. J Environ Qual 28(6): $1727-1732$ 